DOI: $10.19195 / 0137-1150.167 .50$

\author{
FILIPPO CAMAGNI
}

Uniwersytet Jagielloński, Polska

\title{
Человеческое бессмертие в романе Евгения Водолазкина Авиатор
}

Евгений Водолазкин в романе Авиатор, опубликованном в 2016 году, выбирает совершенно другую повествовательную структуру, нежели в предыдущем романе - Лавр ${ }^{1}$, он также отказывается от лексических особенностей древнерусских летописей в пользу более „нейтрального” языкового регистра, но, несмотря на это, почерк мастера узнаваем. И дело не столько в стилистических сходствах обоих романов, сколько в выборе тематики. В Авиаторе на первый план выходят размышления над условностью линейного (исторического) времени в связи с художественным пространством, а также затронуты вопросы вечности, человеческого бессмертия и отсутствия времени. Но если в Лавре духовный путь ведет главного героя через постепенное отречение „от мира сего” к вечной жизни, то в Aвиатоpe герои решают экзистенциальные вопросы, разрабатывая определенные „жизненные стратегии”, ведущие к личному бессмертию. В данной статье мы сосредоточимся именно на выявлении и анализе этих стратегий.

Известный польский и британский философ Зигмунт Бауман исследовал понятие „жизненная стратегия” с социологической точки зрения, сквозь призму страха человека перед смертью и влияния этого страха на мировую культуру ${ }^{2}$. Согласно Бауману, современный человек, ощущая безысходность и обреченность своего существования, все-таки прилагает усилия, чтобы не болеть, заботиться о себе и жить как можно дольше. Эта ,амбивалентность бытия” заставляет разрабатывать личную жизненную стратегию, направленную на увеличение продолжительности жизни и максимальное отдаление смерти - особенно в условиях так называемого „те-

1 За роман Лавр (2012) в 2013 году Е. Водолазкин получил премии „Большая книга” и „Ясная Поляна”.

2 Z. Bauman, Mortality, Immortality, and Other Life Strategies, Cambridge 1992. 
кущего общества", когда принять неизбежность смерти стало еще труднее, а „смотреть ей прямо в лицо практически невыносимо”.

Жизнь главного героя романа Авиатор, петербуржца Иннокентия Петровича Платонова, радикально меняется в результате Октябрьской революции: 17-летний герой переживает загадочную смерть отца на Варшавском вокзале, за ней следует принудительное переселение в коммуналку, где Платонов знакомится с Настей, своей будущей возлюбленной. В 1937 году за убийство соседа-доносчика Платонов осужден и отправлен в Соловецкий лагерь особого назначения, где ученые ставят опыты на заключенных в рамках научного эксперимента по криоконсервации ${ }^{4}$, замораживая их ${ }^{5}$. Проснувшись после заморозки, Платонов обнаруживает, что ничего о себе не помнит. Чтобы восстановить память и собственную историю, он начинает записывать свои медленно и нечетко проявляющиеся воспоминания в дневнике, а затем с удивлением обнаруживает, что провел в спячке более 60-ти лет, и на календаре - 1999 год.

С выведением Платонова из крионической заморозки связана в Авиатоpe первая жизненная стратегия. Поскольку современная медицина еще не в состоянии выводить из заморозки без повреждения внутренних органов, специалисты-крионики надеются, что благодаря научно-техническому развитию в будущем человечество сможет не только эффективно размораживать замороженные тела, но и лечить болезни, которые сегодня считаются неизлечимыми 6 . В этом контексте крионику можно считать своеобразной жизненной стратегией, позволяющей сделать человеческую жизнь неограниченно долгой и достичь, согласно определению теоретика научно-

${ }^{3}$ Там же, с. 45.

${ }^{4}$ Крионика - практика замораживания и консервации тела в состоянии клинической смерти, проводящаяся с использованием жидкого азота, который обеспечивает остановку биохимических процессов, приводящих к разложению.

${ }^{5}$ В биографии Максима Горького Павел Басинский упоминает о том, что писатель, уповая на достижение человеческого бессмертия, обратился к Сталину именно с просьбой о содействии в создании Всесоюзного института экспериментальной медицины, а вождь поддержал эту идею (П. В. Басинский, Горький, Москва 2005). Можно предположить, что Водолазкин неслучайно вводит в канву повествования профессора Муромцева — руководителя эксперимента по криоконсервации в Соловецкой лаборатории ЛАЗАРЬ. Как отмечает в своих записях герой романа, Иннокентий Платонов, Муромцев лично общался со Сталиным и знал о живом интересе вождя к такого рода экспериментам. Однако никаких реальных сведений, подтверждающих существование подобных лабораторий в Соловецком трудовом лагере, нет.

6 По мнению сторонников крионики, этот научный метод - первый практический шаг на пути к „всеобщему воскрешению” (определение Н. Ф. Федорова). В Авиаторе присутствует ряд аллюзий к Федорову. Например, Настя пишет в дневнике: „[...] как подробно он описывает всяческие детали, и чем старше они - тем с большей любовью! Я ему сказала об этом, а он ответил, что пишет проект грядущего всеобщего восстановления мира". См.: Е. Г. Водолазкин, Авиатор, Москва 2016, с. 277. Далее ссылки на это издание даются в скобках после цитаты. 
го иммортализма ${ }^{7}$ Игоря Вишева, „практического бессмертия” человека. В Авиаторе технология замораживания людей представлена уже на первых страницах романа: доктор Гейгер, лечащий врач Платонова, приносит ему книгу создателя концепции крионики, американца Роберта Эттингера ${ }^{8}$, и старается постепенно ознакомить главного героя с исключительностью его положения. Будучи первым успешно размороженным человеком, Платонов становится, по собственному определению, настоящим „Лазарем”9.

Иммортализм в Советском Союзе начал развиваться в 1920-е годы; уже тогда пропаганда активно продвигала идею, что „при коммунизме научными средствами упразднится смерть"10. Как отмечает американская культуролог Ирен Мазинг-Делич, понятие физического бессмертия человека толковалось в СССР неоднозначно: отвергая всякие перспективы вечного существования человеческой души в трансцендентальном измерении, советские идеологи никогда не отрицали возможности достижения физического бессмертия с помощью технического прогресса ${ }^{11}$. Хотя во многих литературных произведениях того времени появлялась надежда на вечную жизнь ${ }^{12}$, власти СССР никогда официально не высказывались по этому поводу, предпочитая доверить тайну человеческого бессмертия куда менее „опасной”, с идеологической точки зрения, жизненной стратегии общественного прославления личности. Согласно Атеистическому словарю, достоинство жизни ,создает не вымысел о личном бессмертии, а осознание человеком своей неповторимости, своего вклада в созидание лучшего бу-

${ }^{7}$ Иммортализм - гуманистическая доктрина, ее последователи занимаются поиском возможных научных способов победы над смертью - в том числе, и крионикой. Как отмечает И. В. Вишев, научный иммортализм стал бурно развиваться во 2-ой пол. XX века, особенно благодаря трудам ботаников Л. В. Комарова (1869-1945) и В. Ф. Купревича (1897-1969), физико-химика П. А. Ребиндера (1898-1972), биолога Г. Д. Бердышева (19302016), геронтолога В. И. Дильмана (1925-1994), философа Л. Е. Балашова (1944) и др. (см.: И. В. Вишев, Проблема бессмертия в истории русской философии, „Челябинский гуманитарий” 2009, № 8, с. 72).

${ }^{8}$ R. C. W. Ettinger, The Prospect of Immortality, New York 1964. Произведение Эттингеpa, одно из самых новаторских произведений XX века в области крионики, было опубликовано на русском языке в 2002 г. (пер. Д. Медведев).

${ }^{9}$ К имени библейского персонажа, воскрешенного Христом, восходит также название соловецкой лаборатории, в котором проводили тайные научные эксперименты по криоконсервации заключённых. „ЛАЗАРЬ” - акроним для „Лаборатории по замораживанию и регенерации".

${ }^{10}$ К. Фрумкин, Бессмертие: странная тема русской культуры, „Новый мир” 2012, № 4, http://magazines.russ.ru/novyi_mi/2012/4/f10.html [дата обращения: 1.05.2017].

${ }^{11}$ I. Masing-Delic, Abolishing Death: A Salvation Myth in Russian Twentieth Century Literature, Stanford 1992.

12 В качестве примера можно, в частности, привести ряд произведений М. Горького: поэму Человек (1903), рассказ Кладбище (1913), повесть Исповедь (1908) и др.; стихотворения В. Маяковского Товарищу Нетте, пароходу и человеку (1926), Разговор с фининспектором о поэзии (1926), Во весь голос (1930) и др.; повести А. Платонова Чевенгур (1929) и Котлован (1930), рассказ Бессмертие (1936) и др.. 
дущего. Подлинное бессмертие человека состоит в сохранении результатов его деятельности" "3. В Авиаторе, однако, Водолазкин не касается вопроса общественной памяти, предпочитая обратить внимание читателя на веру в неудержимое, бескомпромиссное развитие науки, которая, по словам Иннокентия Платонова, заменила духовное измерение. Это хорошо иллюстрирует разговор Платонова с молодой „эмансипанткой” Лерой Амфитеатровой: „-Ты веришь в Бога? / — Да. / - В эпоху аэропланов стыдно быть верующим. Вот я - дочь священника, а не верю. [...] Чего молчишь? / Разве аэропланы отменили смерть? / Лера засмеялась: - Конечно!” [c. 91]. В метонимическом плане аэропланы - воплощение научно-технического прогресса, символ самой практической, „осязаемой” жизненной стратегии, направленной на достижение личного бессмертия. Трудно не уловить интертекстуальную отсылку к стихам Маяковского („Крестьянин / и в этом деле / вот / не поп поможет, / а самолет"14), хотя в воспоминаниях Платонова куда громче звучат фрагменты из поэмы Блока Авиатор: „Уж поздно: на траве равнины / Крыла измятая дуга... / В сплетеньи проволок машины / Рука - мертвее рычага...” [c. 272]. Описание трагической гибели советского летчика, который врезался в землю во время публичных полетов на Комендантском поле в Ленинграде, занимает центральное место в воспоминаниях Платонова. Дело не столько в том, что Водолазкин ,„реконструирует момент гибели летчика, увиденный глазами мальчика Иннокентия [...] опираясь на блоковские подсказки" 15 , сколько в жестком сопоставлении человеческой плоти с безжизненностью машины. Этот образ можно считать в аллегорическом смысле прямым ответом на вопрос о способности технического прогресса „отменить смерть”. Неудача эксперимента по продлению жизни Платонова (вскоре после разморозки у него начинают отмирать клетки мозга) имеет символическое значение: наука не в состоянии осуществить утопический проект Николая Федорова.

Очередной пример символического в прозе Водолазкина - использование писателем семантически заряженных имен собственных. В романах Похищение Европьl, Лавр и Авиатор автор вводит героиню по имени Анастасия. Символика этого имени ${ }^{16}$ позволяет сделать совершенно опреде-

13 А. И. Абдусамедов, Р. М. Алейник, Б. А. Алиева и др., Атеистический словарь, под ред. М. П. Новикова, Москва 1983, с. 56. В известной Диалектике природы Ф. Энгельс высказал похожую мысль: „Смерть есть либо разложение органического тела, ничего не оставляющего после себя, кроме химических составных частей, образовывавших его субстанцию, либо умершее тело оставляется после себя некий жизненный принцип, нечто более или менее тождественное с душой, принцип, который переживает все живые организмы, а не только человека". См.: Ф. Энгельс, Диалектика природы, Москва 1987, с. 258.

14 В. В. Маяковский, Вот для чего мужику самолет (Город-летает. Ушел в поднебесье...), [в:] его же, Полное собрание сочинений в 13 томах, т. 4, Москва 1957, с. 146.

15 И. Чайковская, Возвращение авиатора, „Знамя” 2017, № 2, с. 215.

16 В переводе с древнегреческого Аv $\alpha \sigma \tau \alpha \sigma i \alpha$ - „воскрешенная”, „возвращенная к жизни". 
ленные выводы относительно возможностей интерпретации произведения. Так, в Лавре одна из сюжетных линий романа связана с молодой грешницей Анастасией, у которой главный герой принимает роды, искупая таким образом вину по отношению к Устине, своей возлюбленной: Анастасия становится воплощением умершей во время родов Устины, которая теперь „возвращается в жизнь”. В Авиаторе писатель-демиург повторяет чудо восстания из мертвых: своеобразным воскрешением Анастасии, возлюбленной молодого Иннокентия, становится ее внучка Настя. Платонов пишет в своем дневнике:

О воскрешении думаю все чаще. О нем говорит и Настино имя. Иногда мне кажется, что Настя воскресила Анастасию, что они неразрывны и составляют особую жизнь, нарочно созданную для меня из двух разных жизней. Временами же такая мысль представляется мне безумием, потому что отрицает уникальность всякой отдельной жизни. С уверенностью могу говорить лишь о том, что люблю обеих [с. 285].

Символика имени Анастасия в Aвиаторе усилена - получает дополнительное прочтение ${ }^{17}$. С одной стороны, смерть Анастасии, первой возлюбленной Платонова, неслучайно наступающая в воскресенье, предвещает ее возвращение к жизни - в ипостаси внучки Насти. Отношения Иннокентия с Настей - возможность прожить ту любовь, которая была у него с Анастасией, реализовать тот жизненный сценарий, который писался влюбленными в Ленинграде 1930-х годов и был прерван арестом Платонова. С другой стороны, беременность Насти означает для Платонова не только биологическое продолжение рода, сохранение и передачу своего генетического материала (,уникальность всякой отдельной жизни”), но и метафорическое продление собственной истории. У Платонова появляется возможность, по определению Марии Башмаковой, ,закрепиться в настоящем, оставить в нем свой след"18. Именно в этом - вторая жизненная стратегия Авиатора: с ребенком связана мемориальная функция, будущие поколения становятся хранителями памяти о родителях. Собственно, на

17 С Анастасией связаны и другие авторские размышления экзистенциального характера, предвещающие на сюжетном уровне произведения воскресение героини. Из одного разговора с Платоновым следует, например, что Анастасия ощущает чувство отчаяния перед неизбежностью смерти: „_- Я боюсь не старости... Смерти. Не быть страшно. / А вы были бы готовы не умирать и только все стареть, стареть? / — Не знаю. [...] А почему, чтобы не умирать, нужно обязательно стареть? [...] Если бы был мне дан такой дар - не умирать без всяких условий... [...] То жила бы!” [с. 73]. Затем повествователь размышляет о мимолетности жизни: „А еще я смотрел на Анастасию и думал, что вот, когда-нибудь она тоже увянет, что свежее, светящееся ее лицо сморщится, как арбузная корка. Может ли такое быть? И отвечал: не может” [с. 67]. Образ засохшей корки арбуза - аллегория натюрморта, напоминающая Платонову о проходящей красоте Насти: „Помню, как она сказала, что хочет никогда не умирать [...]. Она и стареть не хотела - может быть, и не постарела? Сомнительно..." [с. 166].

18 М. Башмакова, Чудо рядового „лазаря”, Фонтанка.py, http:/calendar.fontanka.ru/ articles/3696 [дата обращения: 1.05.2017]. 
долю детей, выражаясь словами Федорова, выпадает забота о метафорическом воскрешении близких родственников: „Воскрешение [...] требует общества самостоятельных лиц, сынов, участвующих в общем деле воскрешения отцов. С воспитанием кончается дело отцов, родителей, и начинается дело сынов - воскресителей"19. Важность заботы о сохранении памяти о предках в Авиаторе иллюстрирует и еще один фрагмент: Платонов с Настей приводят в порядок могилы родственников на Смоленском кладбище. Платонов пишет в своем дневнике: „Решил было не выпалывать траву (пусть хоть что-нибудь растет), но Анастасия настояла на том, чтобы выполоть. Сказала, что трава - это зарастание памяти о человеке, что, пока есть кому с этой травою справляться, человек каким-то образом на земле еще присутствует"20 [с. 80].

Все вышеизложенное позволяет раскрыть иной символический пласт семантики имени героини: Анастасия - не только „возвращенная к жизни”, метафорически воплотившаяся в своей внучке, но и предвестие грядущего „воскресения” самого Платонова.

Третья жизненная стратегия, призванная обеспечить личное бессмертие, вводится автором непосредственно в служащем эпиграфом к Авиатору разговоре Платонова с одним из пассажиров на борту самолета:

— Что вы все пишете? / - Описываю предметы, ощущения. Людей. Я теперь каждый день пишу, надеясь спасти их от забвения. [...] если каждый опишет свою, пусть небольшую, частицу этого мира... Хотя почему, собственно, небольшую? Всегда ведь найдется тот, чей обзор достаточно широк. / - Например? / - Например, авиатор [c. 7].

Эта жизненная стратегия заключается не в преодолении физической смерти, а в спасении собственной личности от „забвения”, исчезновения из культурного пространства. С этой целью Платонов старается запечатлеть, сохранить свои воспоминания на бумаге - и таким образом человеческая память становится явлением культуры - текстом. Согласно Юрию Лотману, каждая культура опирается на собственный коллективный интеллект, или „общую память”, которая отвечает за процесс ,актуализации” и „деактуализации" (т. е. исчезновения) находящихся в ней текстов. Письменное произведение, однако, никогда полностью не исчезает из данного культурного пространства, лишь только временно „погасает, переходя в потенцию”21. По мнению Лотмана, „культурная память [...] не только панхронна, но противостоит времени”, сохраняя „прошедшее как пребывающее”22. По-

19 Н. Ф. Федоров, Сочинения, Москва 1982, с. 87.

20 Художественный образ травы связывается с тематикой бессмертия также в романе Михаила Шишкина Венерин волос, где дикорастущий сорняк „,adiantum capillus veneris”, так называемая „травка-муравка”, символизирует вечно возрождающуюся жизнь.

${ }^{21}$ Ю. М. Лотман, Память в культурологическом освещчении, [в:] его же, Избранные статьи, т. 1, Таллинн 1992, с. 201.

22 Там же. 
этому увековечивание личных воспоминаний можно в полной мере считать жизненной стратегией, обеспечивающей человека вечным существованием в культурном пространстве общества ${ }^{23}$.

В романе Водолазкина категории памяти и забвения несут особую смысловую и сюжетообразующую нагрузку. По мнению литературоведа Майи Кучерской, в качестве ключевого сюжетного хода Авиатора избрана амнезия ${ }^{24}$, а критик Григорий Аросев утверждает, что главным героем книги является именно человеческая память ${ }^{25}$. Регулярно записывая на бумаге впечатления о незнакомом ему окружающем мире, Платонов сначала старается лишь восстановить собственную память. Однако после резкого ухудшения состояния здоровья герой понимает, что для своих воспоминаний (,запечатков” - определение Платонова) надо найти „безветренную гавань" [с. 186], безопасное место, способное оградить их от разрушительной силы времени. Платонов чувствует необходимость сохранить себя в письменном форме, закрепить свою личность в дневниковых записях, прочтение которых будет извлекать его из небытия. Он осознает необходимость воплотить свой внутренний мир в записанном слове, сохранить его для потомков. Героя волнует не неизбежность физической смерти, а невозможность познакомиться с собственной дочерью:

Сказал вот на днях Гейгеру, что не намерен больше писать. А теперь понимаю: намерен. Из-за дочери. Если ей не суждено увидеть меня живым, я предстану перед ней, так сказать, в письменном виде, и мои страницы будут сопровождать ее по жизни [c. 336].

Итак, ведение дневника превращается в жизненную стратегию. Неслучайно сборник личных записей Иннокентия Петровича Платонова — на это указывает Водолазкин в фиктивном предисловии к рассказу Трамвай через Неву ${ }^{26}$ - называется Большой книгой жизни.

Согласно эпиграфу к Авиатору, Иннокентий Платонов, последний живой свидетель XIX века, действительно обладает „широким обзором”: описывая предметы, он смотрит с перспективы времени. Однако, выбирая жизненную стратегию, в своих записках герой предпочитает сосредоточиться на деталях, описывая запахи, звуки, самые мелкие подробности, которым прочте-

${ }^{23}$ Как подмечено Григорием Аросевым (см.: Г. Аросев, Важнее настоящегго..) и Майей Кучерской (см.: М. А. Кучерская, В ответе за время...), проблема увековечивающей функции художественного слова затрагивается и в произведениях М. П. Шишкина, особенно в романах Венерин волос (2005) и Письмовник (2010).

${ }^{24}$ М. А. Кучерская, В ответе за время. В романе Евгения Водолазкина „Авиатор” героя разморозили после 60-летнего сна, „Ведомости” 14.04.2016, https://www.vedomosti.ru/lifestyle/ articles/2016/04/14/637779-vodolazkina-aviator [дата обращения: 1.05.2017].

25 Г. Аросев, Важнее настоящего, „Новый мир” 2016, №7, http://magazines.russ.ru/novyi $\mathrm{mi} / 2016 / 7 /$ vazhnee-nastoyashego-evgenij-vodolazkin-aviator.html [дата обращения: 2.05.2017].

26 Е. Г. Водолазкин, Трамвай через Неву, [в:] Большая книга победителей, сост. и подгот. текстов Е. Шубиной, Москва 2015, с. 54. 
ние возвращает жизнь: „На бумаге все крепче, надежнее. Устные рассказы, знаешь ли, размываются в памяти, а то, что написано, - не меняется. И, что важно, это можно перечитывать" [с. 345]. Таким образом Платонов воскрешает утраченную эпоху: его руку водит „всесильный бог деталей” [с. 28], а его слово, как отмечает Майя Кучерская, - животворящее ${ }^{27}$.

В Aвиаторе Водолазкин, продолжая размышления над темой времени $^{28}$, сосредоточивается на разнице между понятиями личной, „малой истории" и истории человечества. И если история человечества выделяет наиглавнейшие с точки зрения глобального исторического процесса события, то малая история складывается из каждодневных, тривиальных действий - таких как „вечерняя беседа на кухне [...] под абажуром с тусклой мигающей лампочкой”, или „шум автомоторов за окном” [c. 380]. Переворачивая классическое представление о значительности мировой истории, в одном из интервью Водолазкин утверждает, что „личная история важнее истории человечества: народы не совершенствуются, совершенствуются люди" 29 . В своем дневнике главный герой Aвиатора стремится к точному до мелочей описанию повседневности - того, „что современникам кажется само собой разумеющимся и не достойным внимания [...], а потом исчезает, никем не описанное - как будто все происходило в вакууме" [с. 196]. Иннокентий Платонов - художник, а не историк. Его интересует лишь существование событий, а не их историческая последовательность. Для него нет событий основных и второстепенных: „Все важно, и все в дело идет - будь оно хорошим или плохим” [c. 410]. Ведь настоящий „жизнеописатель” должен стремиться к полноте выражения, к полноте истины, чтобы уловить то, что „остается за пределами слов и красок” [с. 410]. Рисуя жизнь в мельчайших деталях, Платонов пишет с намерением „пополнить” мир:

Сказав, например, „мое детство”, я не объясню будущей дочери ровно ничего. Чтобы дать ей хоть какое-то представление об этом, я должен буду описать тысячу разных подробностей, иначе ей не понять, в чем состояло тогдашнее мое счастье [c. 410].

По утверждению Евгения Водолазкина ${ }^{30}$, в основе третьей жизненной стратегии Авиатора лежит особенная интертекстуальная составляющая. Дело не только в очевидной параллели между Иннокентием Платоновым

27 М. А. Кучерская, В ответе за время...

28 Данная проблематика затронута и в других произведениях писателя: Похищение Европь, Соловьев и Ларионов, Лавр, рассказах Совсем другое время, Близкие друзья.

${ }^{29}$ М. Токарева, Евгений Водолазкин: „История человека важнее истории человечества”, „Новая газета” 30.09.2013, https://www.novayagazeta.ru/articles/2013/09/27/56548evgeniy-vodolazkin-171-istoriya-cheloveka-vazhnee-istorii-chelovechestva-187 [дата обращения: 1.05.2017].

30 К. Дронова, ,Авиатор” Евгения Водолазкина, Сизонс проджект, http://seasons-project. ru/life/life-people/aviator-evgeniya-vodolazkina [дата обращения: 1.05.2017]. 
и Робинзоном Крузо Даниэля Дефо (по ходу повествования Платонов неоднократно сравнивает себя с путешественником, который, попав на необитаемый остров, старается восстановить знакомый ему мир по деталям ${ }^{31}$ и навсегда ,запечатлеть” собственную личность ${ }^{32}$ ). Следует также обратить внимание на интертекстуальные связи романа с творчеством Андрея Платонова, который в своих произведениях не только выражал живой интерес к федоровской идее всеобщего воскрешения, но и затрагивал проблему человеческого бессмертия. Главный герой Авиатора не только является однофамильцем писателя, но и во многом напоминает его Вощева из Котлована. Вощев в постоянном поиске, жизненного смысла" и с целью обнаружить абсолютную истину существования собирает в заплечный мешок „всякие предметы несчастья и безвестности” 33 , спасает „утильсырье” от пыли забвения: „Ты не имел смысла жизни, [...] лежи здесь, я узнаю, за что ты жил и погиб. Раз ты никому не нужен и валяешься среди всего мира, то я тебя буду хранить и помнить" ${ }^{\prime 4}$. И все это в перспективе грядущего „всеобщего воскрешения" - обретения ожидаемой истины жизни. Также поступает с мельчайшими свидетельствами малой истории и „жизнеописатель” Иннокентий Платонов.

Связь между Авиатором и Котлованом становится еще более очевидной благодаря Насте: но если Котлован завершается именно трагической смертью девочки, означающей для Вощева крушение всех надежд на открытие „жизненного смысла”, то в Авиаторе смерть Анастасии, возлюбленной Иннокентия Платонова, становится прелюдией к вечной жизни.

Итак, в романе Евгения Водолазкина Авиатор, следуя за Зигмунтом Бауманом, можно выявить три „жизненных стратегии”. Первая, связанная с технологией замораживания и консервации, на сюжетном уровне произведения обречена на поражение. Вторая стратегия связана со смертью и „возвращением к жизни” Анастасии, обусловливающим воскрешение Платонова, метафорическое продление его истории в памяти будущих поколений. Третья стратегия заключается в письменном фиксировании личных воспоминаний при одновременном стремлении к полному отображению быта и детальному описанию личного жизненного опыта. Этот процесс не только защищает человека от уничтожающего воздействия „большой истории”,

${ }^{31}$ И. Богатырева, Слепая Фемида русской истории, „Октябрь” 2016, № 12, с. 150.

32 Как говорит Михаил Шишкин в интервью Язык - это оборона, литературный язык выполняет оборонительную функцию, охраняет человеческую индивидуальность перед воздействием времени, как маленький „островок слов”, полностью окруженный Летой, адской рекой забвения. См.: „Язык - это оборона” Михаил Шишкин о новом типе романа, русском языке и любви к Акакию Акакиевичу, „Критическая масса” 2005, № 2, http:// magazines.russ.ru/km/2005/2/sh3.html [дата обращения: 1.05.2017].

33 А. П. Платонов, Котлован, [в:] его же, Собрание сочинений. В 8 томах, т. 3, Москва 2009, c. 197.

34 Там же, с. 198. 
но и становится индивидуальным путем к вневременному существованию в определенном культурном пространстве. „Человека нет уже, а книга, да, продолжает жить” [с. 139].

\section{Библиография}

Абдусамедов А. И., Алейник Р. М., Алиева Б. А. и др., Атеистический словарь, под общ. ред. М. П. Новикова, Москва 1983.

Аросев Г., Важнее настоящего, „Новый мир” 2016, № 7, http://magazines.russ.ru/novyi_ $\mathrm{mi} / 2016 / 7 /$ vazhnee-nastoyashego-evgenij-vodolazkin-aviator.html [дата обращения: 2.05.2017].

Басинский П. В., Горький, Москва 2005.

Башмакова М., Чудо рядового „лазаря”, Фонтанка.py, http://calendar.fontanka.ru/articles/3696 [дата обращения: 1.05.2017].

Богатырева И., Слепая Фемида русской истории, „Октябрь” 2016, № 12.

Вишев И. В., Проблема бессмертия в истории русской философии, „Челябинский гуманитарий” 2009, № 8.

Водолазкин Е. Г., Авиатор, Москва 2016.

Водолазкин Е. Г., Трамвай через Неву, [в:] Большая книга победителей, сост. и подгот. текстов Е. Шубиной, Москва 2015.

Дронова К., ,,Авиатор” Евгения Водолазкина, Сизонс проджект, http://seasons-project.ru/life/ life-people/aviator-evgeniya-vodolazkina [дата обращения: 1.05.2017].

Кучерская М. А., В ответе за время. В романе Евгения Водолазкина „Авиатор” героя разморозили после 60-летнего сна, „Ведомости” 14.04.2016, https://www.vedomosti.ru/ lifestyle/articles/2016/04/14/637779-vodolazkina-aviator [дата обращения: 1.05.2017].

Лотман Ю. М., Избранные статьи, Таллинн 1992.

Маяковский В. В., Полное собрание сочинений в 13 томах, Москва 1957.

Платонов А. П., Собрание сочинений. В 8 томах, Москва 2009.

Токарева М., Евгений Водолазкин: „История человека важнее истории человечества”, „Новая газета" 30.09.2013, https:/www.novayagazeta.ru/articles/2013/09/27/56548-evgeniyvodolazkin-171-istoriya-cheloveka-vazhnee-istorii-chelovechestva-187 [дата обращения: 1.05.2017].

Федоров Н. Ф., Сочинения, Москва 1982.

Фрумкин К., Бессмертие: странная тема русской культуры, „Новый мир” 2012, № 4, http:// magazines.russ.ru/novyi_mi/2012/4/f10.html [дата обращения: 1.05.2017].

Чайковская И., Возвращение авиатора, „Знамя” 2017, № 2.

Язык - это оборона. Михаил Шишкин о новом типе романа, русском языке и любви к Акакию Акакиевичу „Критическая масса” 2005, № 2, http://magazines.russ.ru/km/2005/2/ sh3.html [дата обращения: 1.05.2017].

Энгельс Ф., Диалектика природь, Москва 1987.

Bauman Z., Mortality, Immortality, and Other Life Strategies, Cambridge 1992.

Ettinger R. C. W., The Prospect of Immortality, New York 1964.

Masing-Delic I., Abolishing Death: A Salvation Myth in Russian Twentieth Century Literature, Stanford 1992. 


\section{Human immortality in Eugene Vodolazkin's novel The Aviator}

\section{Summary}

The purpose of the article is to identify and analyze in Eugene Vodolazkin's newest novel The Aviator (2016) the so-called "life strategies", leading fictional characters to their personal immortality. Zygmunt Bauman defines the concept of "life strategy" as a natural, almost instinctive effort to push away death and extend our own existence throughout time and space. In fact The Aviator's main character, Innokentii Petrovich Platonov, in the attempt to restore his memory after decades of cryogenic storage, struggles with the possibility to record and set down in some permanent form the details of his life, as well as his individual existence, for the next generation to come. In Vodolazkin's novel the research of immortality deals as well with the problem of memory, oblivion, and human frailty.

Keywords: immortality, memory, strategy, Vodolazkin, Aviator

\section{Nieśmiertelność człowieka \\ w powieści Jewgienija Wodołazkina Awiator}

\section{Streszczenie}

Celem artykułu jest zidentyfikowanie i poddanie analizie tak zwanych strategii życiowych w najnowszej powieści Jewgienija Wodołazkina Awiator (2016), które prowadzą jej bohaterów ku osobistej nieśmiertelności. Zygmunt Bauman definiuje koncepcję strategii życiowej jako naturalną, prawie odruchową próbę człowieka odsunięcia śmierć i przedłużenia własnego istnienia w czasie i przestrzeni. Główny bohater Awiatora, Innocenty Płatonow, próbując odzyskać pamięć po dziesięcioleciach przebywania w stanie kriogenicznego zamrożenia, usiłuje zapisać dla następnych pokoleń szczegóły swego życia, będące świadectwem jego doświadczeń. W powieści Wodołazkina poszukiwania nieśmiertelności są powiązane z kwestią pamięci, przemijania i zapomnienia.

Słowa kluczowe: nieśmiertelność, pamięć, strategia, Jewgienij Wodołazkin, Awiator 